\title{
2020 Distance Meeting: Farewell to Professor David Yaffe - A pillar of the myogenesis field
}

\author{
Robert H. Singer \\ Department of Anatomy and Structural Biology, Albert Einstein College of Medicine, New York, \\ NY, USA \\ This article is distributed under the terms of the Creative Commons Attribution Noncommercial License (CC BY-NC 4.0) which permits \\ any noncommercial use, distribution, and reproduction in any medium, provided the original author(s) and source are credited.
}

\begin{abstract}
David Yaffe, PhD passed away on July 3, 2020 at the age of 91. His funeral and burial were held at his kibbutz in Israel, Givat Brenner. At the time of his death, he was emeritus professor of molecular cell biology at the Weizmann Institute of Science. If there is one word to describe David, it would be "pioneer", Halutz in Hebrew. He participated in the birth of his country as a soldier during the War of Independence, contributed his efforts to expanding the kibbutz movement and the nascent scientific community in Israel. He was a major figure in creating the field of muscle cell biology by generating the immortalized cell lines that could be induced to differentiate into muscle fibers in tissue culture. This made myogenesis a prime candidate for studying cell differentiation, accessible to hundreds of scientists during the dawn of molecular cell biology. Many prominent scientists, among them students of David made their careers on studying the molecular events that occurred as the myoblast cell lines developed into the syncytial myofibers that twitched spontaneously. This opened the field to studies on muscle diseases, such as muscular dystrophy, that could then be addressed through a tractable model for molecular studies. David claimed he was never paid for his scientific activities; his salary at the Weizmann Institute went directly to the kibbutz in compensation for his time taken away from work there. He never knew what his salary was, he said, since it was negotiated between the kibbutz and the Weizmann. Even so, he had to take off weeks from his science occasionally to perform daily tasks, usually in the kibbutz dining hall washing dishes. Disconnected from the material aspects of life, David was driven solely by his love for nature and science, which he continued until the very end. David remains an inspiration to all of us. In this issue several of David Yaffe's lab members, pupils, coauthors and colleagues meet at a "David Yaffe myogenesis distance meeting" to pay tribute with their collective reflections.
\end{abstract}

Key Words: Professor David Yaffe, myogenesis, myoblasts, Weizmann Institute of Science

Eur J Transl Myol 2020; 30 (3): 9327. doi: 10.4081/ejtm.2020.9327

In this issue, in an accompanying manuscript by Yablonka-Reuveni et al., ${ }^{1}$ several of David Yaffe's pupils, coauthors and colleagues meet again at a "David Yaffe myogenesis distance meeting" to pay tribute with their collective reflections. Some of them have been members of the Yaffe lab, others have known David as colleagues in the myology field. We appreciate the European Journal of Translational Myology for providing a platform for holding this 2020 distance meeting "Farewell to Professor David Yaffe - A Pillar of the Myogenesis Field".

\section{I add below some of my own personal recollections}

I first met David at the MIT - Massachusetts Institute of Technology in 1971, where I was a postdoctoral fellow with Sheldon Penman. As a new $\mathrm{PhD}$ in Biology at Brandeis, where I studied chicken morphogenesis, I was there to learn about the new field of Molecular Biology, particularly RNA, which I hoped I could apply to the understanding of cell differentiation and development. David was doing a sabbatical at MIT as a guest of Alex Rich. I knew about his work on muscle development so met with him in his office to see if there was some opportunity to collaborate and I wanted to explore the possibility of going to Israel. I walked into his office smoking a cigarette (it was marginally acceptable in those days) and crushed it out on the floor. He looked at me and said "would you do that in your own home?" "Of course not" I said. "Then why would you do it in my office?" I realized that not only did he make a good point but he was capable of telling me exactly what he was 


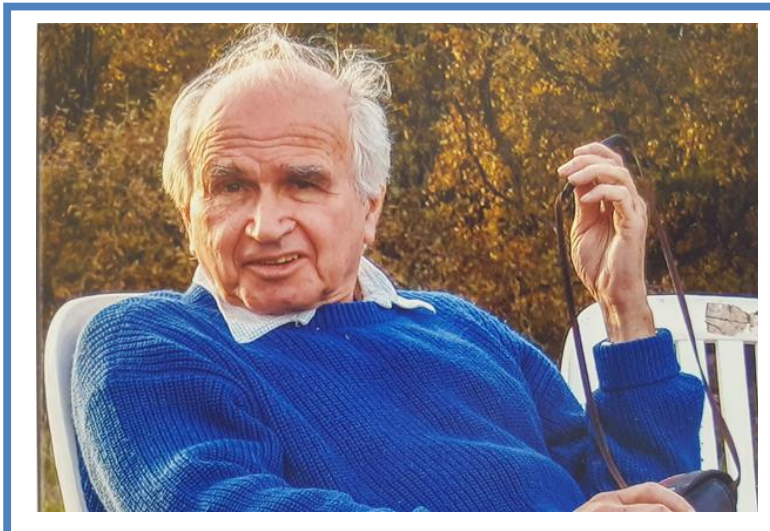

Fig 1. This recent photo of Prof. David Yaffe was kindly provided by Ruth Yaffe.

thinking. This attribute made working with him easy, because we could be direct with each other. He always treated me as an equal. We wrote a successful Muscular Dystrophy Association fellowship for my research with him. We arrived in Israel with my family by boat from Athens in February 1973. I told David when I was arriving, but forgot to tell him it was by boat. He called all the airlines before he discovered we were coming by sea, and sent someone to pick us up in Haifa. He had arranged a villa for us in Rehovot and stocked the refrigerator with food. The backyard was a Garden of Eden with fruit and avocado trees. He went far beyond what I expected of a host and I always appreciated his thoughtfulness. During the Yom Kippur War, he constantly reassured us that everything would be OK. When the car I purchased didn't arrive, he called up the dealer to expedite it. He would organize nature hikes in various Wadis on the weekends, and describe the flora along the way. My project turned out to be harder than I thought it would be. It was to isolate mRNA from differentiating muscle cells in culture. Molecular cloning had not yet been invented. The only way to identify the mRNA was by molecular weight, inferred from the molecular weight of the protein. Bryan Roberts and Bruce Paterson had managed to get mRNA to translate mammalian proteins in a cell-free system, so that was a breakthrough to identify mRNA that could be cut from a gel and used to make the protein, or many proteins as there were many mRNAs contaminating the desired species. Working with a wonderful graduate student, Gania Kessler-Icekson, we had to restrict ourselves to looking for abundant mRNAs, such as actin, or isolated polyadenylated RNA. ${ }^{2,3}$ Not until many years after I left Israel did I achieve this, but the difficulties led me to develop in situ hybridization as a tool to investigate single muscle cells in culture and correlate gene expression of actin mRNA with cell morphology during differentiation. ${ }^{4}$ I essentially made my career on the study of actin mRNA, which began there. Without my experience in Israel working with David, I don't think this career path would have happened. And I remember all the wonderful people in the lab at that time, Sara, Ora, Zipora, Gad, Haviv and others. When I last saw David in his cluttered office in 2018, he looked exactly the same as when I remembered him, impervious to aging. I will always be grateful to him for my introduction to Zion and for his mentorship. Although I have strayed from the muscle field, it remains the platform that launched me.

\section{Acknowledgments}

I would like to thank Zipora Yablonka-Reuveni for arranging for this contribution, for providing insightful comments and discussion, and for helping to augment my memory.

\section{Funding None}

\section{Conflict of Interest}

None.

\section{Ethical Publication Statement}

We confirm that we have read the Journal's position on issues involved in ethical publication and affirm that this report is consistent with those guidelines.

\section{Corresponding Author}

Robert H. Singer, Anatomy \& Structural Biology, Albert Einstein College of Medicine, New York, NY, USA.

ORCID iD: 0000-0002-6725-0093

Email: robert.singer@einsteinmed.org

\section{References}

1. Yablonka-Reuveni Z, Stockdale F, Nudel U, Israeli D, Blau HM, Shainberg A, Neuman S, KesslerIcekson G, Meghid Krull E, Paterson B, Saxel Fuchs O, Greenberg D, Sarig R, Halevy O, Ozawa E, Katcoff DJ. Farewell to Professor David YaffeA Pillar of the Myogenesis Field. Eur J Transl Myol 2020;30(3):9306. doi.org/10.4081/ejtm.0.9306 https://www.pagepressjournals.org/index.php/bam/ article/view/9306/8904

2. Kessler-Icekson G, Singer RH, Yaffe D. The capacity of polyadenylated RNA from myogenic cells treated with actinomycin D to direct protein synthesis in a cell-free system. Eur J Biochem 1978;88:403-10. doi: 10.1111/j.1432-1033.1978. tb12462.x

3. Singer RH, Kessler-Icekson G. Stability of polyadenylated RNA in differentiating myogenic cells. Eur J Biochem. 1978;88:395-402. doi: 10.1111/j.1432-1033.1978.tb12461.x

4. Lawrence JB, Taneja K, Singer RH. Temporal resolution and sequential expression of musclespecific genes revealed by in situ hybridization. Dev Biol 1989;133:235-46. doi: 10.1016/00121606(89)90314-x

Submitted: August 28, 2020 Accepted for publication: August 29, 2020 